\section{Jane Haladay, Scott Hicks (Ur.) NARRATIVES OF EDUCATING FOR SUSTAINABILITY IN UNSUSTAINABLE ENVIRONMENTS}

Michigan State University Press, Michigan, 2018., xxviii + 278 str.

Godine 2018. u izdanju Michigan State University Pressa tiskana je knjiga aktualne i nadasve izazovne tematike, koju su uredili profesori sa Sveučilišta Sjeverne Karoline u Pembroku - Jane Haladay i Scott Hicks. Radi se o vrlo opsežnom djelu koje je objedinilo iskustva profesora koji poučavaju na humanističkim studijima o visokom obrazovanju i održivom razvoju s raznih sveučilišta širom svijeta. Fokus je knjige na otvorenom i iskrenom iznošenju iskustava rada u visokom obrazovanju i mogućnostima primjene poučavanja o održivu razvoju u nastavi. Osim o pozitivnim promjenama i metodama (poučavanje proznim djelima, dokumentarcima, provođenjem projekata sa studentima, poučavanjem na otvorenom), autori raspravljaju i o barijerama s kojima se susreću u svojem radu (izostanak financijske podrške lokalnih vlasti, niska razina podrške vodećih na sveučilištima i slično). Pojam održivosti veoma je širok i danas još uvijek mnogima nejasan. Stoga važnu ulogu u ovome ima visoko obrazovanje, koje, između ostalog, obrazuje buduće odgajatelje, učitelje, profesore i nastavnike raznih profila. Kao što već $\mathrm{u}$ predgovoru ističu urednici, bez visokog obrazovanja pojam održivosti može značiti različite stvari za svakoga pojedinca, institucije i zajednice - ovisno o tome tko je, gdje i kako studirao i promišljao o održivosti. Knjiga sažima osobne i profesionalne priče autora koji se suočavaju s izazovima u poučavanju održiva razvoja na fakultetima na kojima rade te pruža dubok uvid u situacije, okolnosti, metode i tehnike koje se pojavljuju u njihovu radu.

U skladu s proučavanom tematikom, a radi prikupljanja informacija koje će pružiti kolektivne odgovore, urednici polaze od tri temeljna pitanja koja vode zajedničkom cilju - osvještavanju važnosti o visokom obrazovanju u učenju o održivom razvoju: 1) kako profesori obrazuju za održivost i što to znači iz perspektive humanista koji reflektiraju svoju praksu u ovoj knjizi?; 2) kako se održavaju kao nastavnici u sustavima, mjestima i ekologijama u kojima poučavaju kao pomoćni ili redoviti profesori; i 3) kako se nose sa sustavima koje su vanjske grupe različito usmjerile na transformaciju, reformu ili uklanjanje. Struktura knjige (knjiga se sastoji od tri dijela; prvi dio sadrži pet radova, dok drugi i treći dio sadrže po četiri rada raznih autora) jasno i iscrpno odgovara na ova početna pitanja uredničkoga tandema. Elaboriranje je u svim radovima utemeljeno na recentnoj stručnoj i znanstvenoj literaturi, prikazom mjesta iz kojeg autor/i dolazi/e, autorovim iskustvima $\mathrm{u}$ neposrednom radu sa studentima te implikacijama i preporukama za budući rad. U prvom dijelu autori detaljno iznose vlastita iskustva o suočavanju s izazovima na radnom mjestu i (ne)mogućnostima održivosti s obzirom na radne uvjete i percepcije vodećih tijela na sveučilištu i vodećih institucija u zajednici, kao i samih studenata. Drugi dio posvećen je razmišljanju o onome što radimo i kako strukturiramo kurikul(um) za održivi razvoj. Naglasak je na praktičnim metodama, zadacima i projektima koje provode sami studenti, kasnije zajednički uspoređujući dobivene rezultate. Treći dio donosi zanimljive refleksije nastavni- 
ka koji ističu važnost jačanja osobnih profesionalnih kompetencija za održivost, poštovanje autohtonih epistemiologija te poticanje otvorenih učionica za poučavanje održivog razvoja. Na kraju svakog rada nalaze se bilješke i literatura, a zaključna razmatranja iznesena su u epilogu.

Koji su načini poučavanja održivog razvoja i s kojim se izazovima susreću profesori u neposrednom radu sa studentima, detaljno je prikazano u prvom dijelu knjige ("Confronting the Challenges of the Places We Are"). Šestero autora donosi svoju priču, pa tako rad ("Unrooted: Dislocation and the Teaching of Place") autorice J. L. Case opisuje probleme i barijere s kojima se susreću mladi ljudi, studenti ili profesori prilikom napuštanja rodnoga mjesta i odlaska na studij ili rad u novo okruženje. Naglašava važnost metode pisanja, u kojoj studenti izražavaju svoj pogled na mjesto iz kojega dolaze. Smatra da bez visokog obrazovanja i dobrih temelja koje mogu ponuditi profesori studentima, i obrnuto, nema kvalitetnog obrazovanja za održiv razvoj. Urednici knjige svojom pričom ("By the Lumbee River with Chad Locklear's 'Swamp Posse"') objašnjavaju mogućnosti i izazove povezivanja literarnih tematskih jedinica o okruženju s pričama koje govore o mjestu u kojem se nalaze. Takav način rada omogućuje studentima učenje kroz praktični dio iznošenjem vlastitih mišljenja i ideja koje povezuju obrađivano djelo i ideju koncepta održivog razvoja. Autor D. Spoth ("Getting Your Feet Wet: Teaching Climate Change at Ground Zero") opisuje važnost i izazove pedagogije koja će kreirati buduće generacije koje će postati vođe $\mathrm{u}$ provođenju promjena, koji će se boriti protiv barijera koje nas zaustavljaju u provođenju akcija i koji će se suočiti s klimatskim promjenama. Svjestan težine izazova, zbog studenata koji dolaze iz raznih krajeva i koji će vjerojatno otići daleko kada diplomiraju ili koji visoko obrazovanje vide samo kao stepenicu u daljnjem razvoju, autor naglašava da nije dovoljno osvještavati samo pojedince. Nasuprot tome, a ovdje dijelimo mišljenje s autorom, pedagogija treba pomoći studentima u formiranju zajednice i širih odnosa koji će naglašavati povezanosti koje čine održivost. Tu zaključuje kako obrazovanje za održivost mora probuditi i potaknuti emocije studenata i zalaže se za optimizam $u$ radu sa studentima, jer ako se žele postići promjene, tada mlade treba poučavati da mogu promijeniti svoju okolinu nabolje. Autorica B. R. Burke piše o težini poučavanja o održivom razvoju u neodrživoj okolini. Uvjerljivo ističe koliko mogu biti povezani naš sustav dobivanja energije i naši osobni i profesionalni životi. Prikazujući svoj rad ("Cutting through the Smog: Teaching Mountaintop Removal at a University Powered by Coal"), u kojem raznim pričama, dokumentarcima i izletima dopire do studenata, objašnjava koliko je teško poučavati održivost na sveučilištu koje kao primarni izvor energije rabi jedan od najvećih zagađivača zraka - ugljen. No usprkos tome, jasno naglašava investiranje $u$ nadu za budućnost svojih studenata da vjeruju kako mogu težiti svijetu koji će biti održiv, socijalan i ekološki i da oni mogu donijeti promjene koje su svijetu potrebne. J. Schell zatvara prvi dio knjige pedagoškim esejom ("Teaching about Biodiversity and Extinction in a Thawing Alaska: A Reflection"), u kojem opisuje ekološke, ekonomske i geopolitičke zapreke s kojima je bila suočena kao članica Sveučilišta Fairbank na Aljasci. Aljaska je jedina zemlja u SAD-u koja ne skuplja porez na dohodak i porez na prodaju kako bi pomogla podržati javno obrazovanje. Sve to rezultira smanjenjem budžeta, koji rezultira manjim brojem putovanja, manjim brojem istraživanja i kreativnih aktivnosti, a većim udjelom teorijske nastave. Njezina inicijativa da u svojem nastavnom radu pokrene promjene u poučavanju donijele su drukčiju pers- 
pektivu njezinim studentima u sagledavanju tematike održivog razvoja. Drugi dio knjige ("Rethinking What We Do, Remaking Curricular Ecologies") započinje radom D. Owensa. U njemu se opisuje snaga pedagogije u osvještavanju ekološke krize. U svojem radu ("Letting the Sheets of Memory Blow on the Line: Phantom Limbs, World-Ends, and the Unremembered") Owens raspravlja o tri tipa održivosti: ekonomska održivost, ekološka održivost i socijalna održivost, pri čemu posebno naglašava kulturnu održivost kao dimenziju socijalne održivosti. Pritom piše kako je njihovo sveučilište ispunjeno različitošću - $\mathrm{i}$ to jezičnom, rasnom, etničkom i duhovnom - što se pokazalo kao pozitivno u poučavanju o održivom razvoju i u razmjeni iskustava, prilikom čega je uzet širok spektar tehnika i metoda kako bi na praktičan način $u$ radu i nastavi zaživjela tematika održivosti. Vodeći se sličnim mislima, C. Taylor, R. House i M. Minster pokreću program HERE (Home for Environmentally Responsible Engineering) na Rose-Hulman Institutu tehnologije u Terre Haute u Indiani, želeći interdisciplinarnim pristupom osvijestiti kod studenata tehnološkoga fakulteta važnost održivog razvoja. U svojem radu ("Student Expectations, Disciplinary Boundaries, and Competing Narratives in a First-Year Sustainability Cohort") daju pregled početka osnivanja programa, ističu mnoge izazove s kojima su se susretali te, naposljetku, pišu o svojoj viziji budućnosti programa. Nadalje, povezujući svoje iskustvo iz djetinjstva, autorica A. Olive u svojem radu ("Connecting Urban Students to Conservation through Recovery Plans for Endangered Species") iznosi ideju o osvještavanju studenata urbanih krajeva o važnosti krajolika koji ih okružuje. Vlastita is- kustva i težina navikavanja na život u urbanom središtu potaknula su je na pisanje $i$ istraživanje o ugroženim vrstama za koje ne postoji plan oporavka u njihovoj državi/gradu, čemu je težila u radu sa svojim studentima. Takav koncept rada kasnije su prihvatile i lokalne vlasti, koje su najbolje projekte uvrstile u svoj plan rada. Sličnom konceptu teži i K. Byars-Nichols u svojem radu ("Teaching Critical Food Studies in Rural North Carolina"), želeći osvijestiti važnost hrane koja se proizvodi i konzumira u njihovoj okolini. Uvodeći inovativne metode $\mathrm{u}$ rad sa studentima, pokreće tečaj s četiri modula, koji kao rezultat, navodi autorica, potiče studente na ne$\mathrm{ku}$ vrstu transformacije sebe, što uključuje dublje razumijevanje vlastitih stavova, stavova drugih i stvarnosti o konzumiranju lokalno proizvedene hrane.

Treći dio ("Reinhabiting and Restoring Who and Where We Are") donosi alternativne metode obrazovanja za održivi razvoj. Autorica J. Curran u svojem radu ("Mindfulness, Sustainability, and the Power of Personal Practice") kroz raspravu navodi mogućnosti uvođenja joge kao dio nastavnoga procesa. Naglašava nužnost traženja i pronalaženja izvora osobne snage u raz-voju profesionalne održivosti. Integriranjem joge i meditativnih filozofija u svoj kurikul(um) autorica svojim studentima nudi smislen pristup obrazovanju za okoliš, a u isti mah radi na uspostavljanju održivijega visokoškolskog okruženja. Nešto drukčiji pogled na rad ima autorica B. George ("Ecological Journeys: From Higher Education to the Old Farm Trail"), koja uspoređuje restrukturirano mjesto stare bolnice u gradski park sa stazama, livadama i sportskim terenima koje je rabila kao otvorenu učionicu za poučavanje održivosti, spram teškog održavanja karijere u visokom obrazovanju. Kao voditeljica otvorene učionice $\mathrm{u}$ Pittsburghu, sva stečena iskustva primijenila je $\mathrm{u}$ interdisciplinarnom poučavanju održivog razvoja u nastavi engleskoga jezika. Zaključuje kako je visoko obrazovanje neodrživo mjesto za poučavanje o održivom razvoju ako se $u$ to ne uključi praktičan rad sa studentima 
$\mathrm{u}$ svim nastavnim predmetima. Zadnja dva rada donose raspravu i iskustvo o autohtonim vrijednostima pojedinoga kraja ili jezika. Grupa autora pokrajine Bawaka pišu inspirativan tekst ("Meeting across Ontologies: Grappling with an Ethics of Care in Our Human-More-than-Human Collaborative Work") vodeći se filozofijom "wetj", koju definiraju kao "dijeljenje i odgovornost". Želeći se oduprijeti frustrirajućim barijerama i neodrživom radu, odlučili su se voditi etikom brige, dijeljenja i zajedničkoga stvaranja, bez obzira na to odakle tko dolazi, dokazujući da različitosti mogu pridonijeti boljem shvaćanju koncepta održivosti. Zadnji rad ("Ganawendamaw: Anishinaabe Concepts of Sustainability") autorice M. Noodin približava značenje autohtonoga jezika - anishinaabe. Autorica smatra da je najbolji način za poučavanje o ugroženim konceptima održivih ekoloških odnosa upravo uz pomoć ugroženoga, autohtonog jezika. Iako postoje mnogi izazovi u održavanju autohtonoga jezika i kulturne prakse toga naroda, autorica svojim radom dokazuje kako njezina pedagogija, ispreplećući jezik anishinaabe i priče, teži održivosti kulture njezina naroda, ali i nje same.

Epilog donosi zaključke i završna razmatranja urednika knjige. Autori ističu kako je važno svakodnevno naglašavati ulogu svakoga pojedinca u očuvanju našeg planeta. S obzirom na štete koje su učinjene i koje se ne mogu više ispraviti, autori pozivaju sve one koji rade $\mathrm{u}$ visokom obrazovanju da se suoče s činjenicama i da osvijeste važnost pokretanja inicijative za održivost. Uvjeti za primjenu interdisciplinarnoga pristupa poučavanja o održivom razvoju u ostale nastavne predmete često ne idu na ruku sveučilišnim profesorima, pogotovo $\mathrm{u}$ okolinama koje nisu spremne na nove uloge i nove zadaće, međutim, kao što pišu autori, ova knjiga dokaz je da se može mijenjati praksa ako postoje uporni i motivirani pojedinci od kojih će poteći inicijativa. Autori su zahvalni svim visokoškolskim institucijama koje provode projekte koji se odnose na bilo koju dimenziju održivog razvoja te zaključuju i naglašavaju da upravo svi mi možemo i trebamo postati snaga koja će mijenjati visokoškolsko obrazovanje i, s druge strane, spasiti naš planet.

Ova knjiga vrijedan je doprinos i akademskoj i široj zajednici, prožeta je povezivanjem teorije i prakse i praćenjem dostignuća novih istraživanja u tome području. Svaka od tih priča vodi istom cilju osvještavanju važnosti uključivanja obrazovanja za održivi razvoj u visoko obrazovanje. $U$ tom smislu, ne misli se samo na kolegij u kojem će se učiti o ovoj tematici nego i na integriranje održivog razvoja $u$ svaki kolegij i u svaku znanstvenu disciplinu. Dakle težnja za interdisciplinarnim i transdisciplinarnim pristupom učenju i istraživanju na sveučilištu od ključne je važnosti, a autorima $u$ ovoj knjizi to je uspjelo u njihovu radu.

Jasmina Hadela

https://doi.org/10.5559/di.27.4.10

\section{Luke Martell THE SOCIOLOGY OF Globalization 2nd Edition}

Polity Press, Cambridge, 2016., 277 str.

Na prvu loptu upada u oči kako autor, L. Martell, otvarajući raspravu o globalizaciji, ima potrebu "očistiti teren" u samoj sociologiji kako bi takva rasprava imala potrebnu kakvoću. Nije, dakako, to "čišćenje terena" zamašno koliko sama složenica sugerira, a ne treba ni biti. Svodi se na, više nego korisno, autorovo isticanje nekih teorijskih i metodologijskih orijentira u so- 